\title{
EVALUATION OF THE ORGANIC SOIL COMPRESSIBILITY FROM IN-SITU AND LABORATORY TESTS FOR ROAD APPLICATION
}

\author{
IWONA CHMIELEWSKA* \\ Department of Geotechnics and Structural Mechanics, \\ Faculty of Civil Engineering and Environmental Sciences, \\ Bialystok University of Technology, Bialystok, Poland
}

Received 22 November 2020; accepted 19 February 2021

\begin{abstract}
Organic soil is characterised by high compressibility and should be improved so that it can be used for construction. The use of every method of soil improvement requires knowledge of the compressibility parameters. One of these parameters is the constrained modulus. The constrained modulus can be determined using laboratory or in-situ tests. In this study, the constrained modulus of organic soil was determined using oedometer and piezocone tests (CPTU). The author analysed subsoil under an approximately $250 \mathrm{~m}$ section of a designed road in north-eastern Poland. The constrained modulus of organic soil sampled from four different depths was determined in oedometer tests. Piezocone tests were conducted at 18 points located every $15 \mathrm{~m}$ along the length of the section concerned. To determine the constrained modulus based on the cone resistance from CPTU tests, the knowledge of the $\alpha$ and $\alpha_{M}$ coefficients is needed. For the tested soil, the optimal range of the $\alpha$ coefficient from 0.4 to 0.7 was determined. The $\alpha_{M}$ coefficient ranged from 0.4 to 0.8 . The value of the constrained modulus of organic soil obtained from the oedometer tests, depending on the effective stress, ranged from approximately $100 \mathrm{kPa}$ to $400 \mathrm{kPa}$. The constrained modulus of the tested soil decreased with depth, which both research methods proved.
\end{abstract}

* Corresponding author. E-mail: i.chmielewska@pb.edu.pl

Iwona CHMIELEWSKA (ORCID ID 0000-0001-6356-1188)

Copyright (C) 2021 The Author(s). Published by RTU Press

This is an Open Access article distributed under the terms of the Creative Commons Attribution License (http://creativecommons.org/licenses/by/4.0/), which permits unrestricted use, distribution, and reproduction in any medium, provided the original author and source are credited. 
Keywords: compressibility, oedometer, organic soil, peat, piezocone penetration

\section{Introduction}

Construction of structures on organic soils is avoided whenever possible. However, rapid development has made construction works on organic soils increasingly inevitable. Organic soils should be improved so that they can be used for construction (Rahman et al., 2016). Many methods of soil improvement are known and used around the world (Duraisamy et al., 2007; Hartlen et al., 1996; Huat et al., 2014; Edil, 2003; Virsis et al., 2020). However, regardless of the method, knowledge of the physical and mechanical parameters of organic soil is required. Determining the parameters of organic soil may be very difficult due to its variable properties even within one deposit (Lechowicz \& Szymański, 2002; Zainorabidin \& Wijeyesekera, 2008) or its ability to change properties with time (Huat et al., 2005). For these reasons, organic soil should be tested in detail and its parameters should be carefully determined using various methods.

One of the organic soil types is peat. Peat is known as partially decomposed plant remains which have accumulated under water conditions for ten to thousands of years (Huat et al., 2009). It has distinctive organic odour and brown to black colour (Huat et al., 2014). The characteristics of peat soil are high water content, low shear strength and high compressibility (Bo et al., 2005; Khalid et al., 2015; Kumar \& Jain, 2013; Majeed \& Taha, 2012; Moon et al., 2019; Wong et al., 2008). In engineering practice, the classification of peat soil is based on the inspection of its structure and consistency. The most commonly used classification system for peat is the von Post scale consisting of 10 steps (Long, 2005). According to the von Post scale, peat can be classified depending on the degree of humification as being between completely undecomposed (H1) and completely composed (H10). Mangan (1994) reduced the von Post scale and divided peat into three types: fibrous, quasi-fibrous (semi-fibrous) and amorphous. The fibrous peat is low-humified and consists of distinct fragments of plant structure. The degree of decomposition of fibrous peat is from $\mathrm{H} 1$ to $\mathrm{H} 4$. The quasi-fibrous peat has medium degree of decomposition (H5-H7) and recognisable structure. In amorphous peat, the plant structure is no visible and the degree of decomposition ranges from H8 to H10.

Many engineering problems in the form of excessive settlement could occur either during or after the construction phase due to high compressibility of peat soil. The settlement reduction to acceptable limits is sometimes of greater significance in construction design than 
limitations imposed by bearing capacity (Head, 1994). This makes the compressibility of organic soils a very important issue for all researchers.

One of the most important compressibility parameters of every soil type is the constrained modulus. The constrained modulus is the most commonly used measure of soil compressibility in engineering practice. Its knowledge is required to predict the settlement or to determine coefficient of permeability (Head, 1994; Powrie, 2014).

The constrained modulus can be determined using laboratory or field tests (Młynarek et al., 2006; Senneset et al., 1989). The laboratory tests for measuring the constrained modulus are conducted in an oedometer or in a consolidometer. Oedometer and consolidometer tests are carried out in one-dimensional conditions in non-deformable ring. One-dimensional loading occurs in the soil beneath an embankment or spread foundation (Atkinson, 2007). The constrained modulus of organic soil is frequently determined using oedometers (Long \& Boylan, 2013). In the field, the constrained modulus can be predicted using flat dilatometer tests (DMT) or cone penetration tests (CPTU). There are two possibilities for estimating the constrained modulus from CPTU data (Lunne et al., 1997): indirectly, based on the undrained shear strength $c_{\mathrm{u}}$, and directly, based on the measured cone resistance $q_{\mathrm{c}}$ or on the corrected cone resistance $q_{\mathrm{t}}$.

Many correlations between the constrained modulus and cone resistance have been described in the literature (European Committee for Standardization, 2007a; Mayne, 2006, 2007; Meigh, 1987; Sanglerat, 1972; Schmertmann, 1978; Senneset et al., 1989; Robertson, 2009). However, correlations for organic soils have been rarely reported.

The prediction of consolidation parameters, such as the constrained modulus, based on the cone resistance and correlating them with the parameters determined in tests without pore pressure measurements may be difficult. However, this is the only way to develop area-specific correlations to obtain parameters with greater reliability (Lunne et al., 1997).

The research area is located in north-eastern Poland in the lake region within the river catchment area. The location is characterised by a great variety of terrain. The subsoil of the area under consideration is composed of the gravel, sand, clayey sand, silt and sandy clayey silt. The peatlands are characteristic of the considered region. Mainly peats with a thickness of about $1 \mathrm{~m}$ to $2 \mathrm{~m}$ could be found in the subsoil. In some locations, the thickness of the organic soils reaches much higher values.

The present research analysed the subsoil under an approximately $250 \mathrm{~m}$ section of a designed road. Peat soil with a thickness of up to 7.5 $\mathrm{m}$ was deposited in the considered subsoil. The constrained modulus of 
organic soil sampled from four different depths was determined using oedometer tests. A total of 20 samples were tested. Piezocone tests were conducted at 18 points located every $15 \mathrm{~m}$ along the length of the section concerned. Constrained modulus of peat soil was determined in piezocone tests, based directly on the cone resistances $q_{\mathrm{c}}$ and $q_{\mathrm{t}}$. The objective of this study was to determine the constrained modulus of organic soil from oedometer and piezocone penetration tests. Additionally, the dependence of the constrained modulus on the depth below the soil surface was determined.

\section{Materials and methods}

\subsection{Materials}

The subsoil under one of the sections of the bypass with a total length of about $12 \mathrm{~km}$ was analysed. The area under consideration was about $250 \mathrm{~m}$ long. Peat (Pt) with a thickness of $2.1 \mathrm{~m}$ to $7.5 \mathrm{~m}$ was found in the considered subsoil. Below the organic soils, glacial sediments in a form of clayey sand (clSa), sandy silt ( $\mathrm{saSi}$ ) and silt ( $\mathrm{Si}$ ) with a very soft, soft and firm consistency were found. The ground water level was at a depth of $0.1 \mathrm{~m}$ to $1.5 \mathrm{~m}$ below the soil surface. The geotechnical cross-section of the analysed subsoil is shown in Figure 1.

The peat was sampled with thin wall cylinders with a diameter of $70 \mathrm{~mm}$. The cylinders were pressed into the subsoil in a vertical direction. Samples were collected from four different depths: $1.2 \mathrm{~m}$,

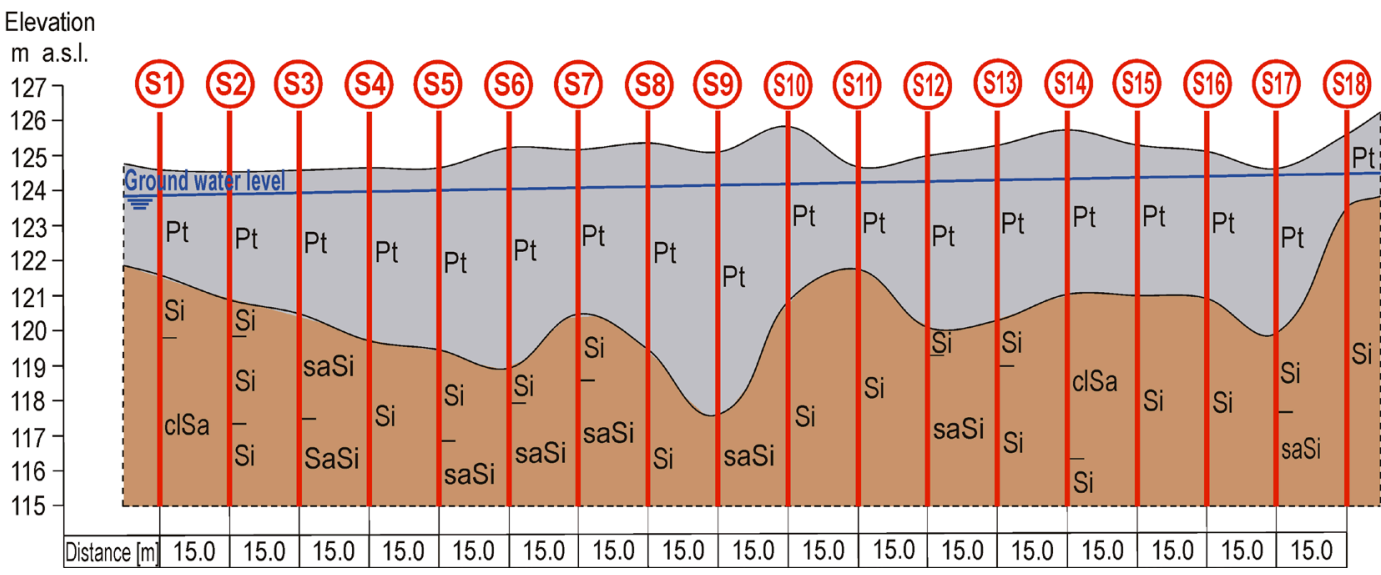

Figure 1. Geotechnical cross-section and piezocone penetration tests locations 
$2.2 \mathrm{~m}, 3.8 \mathrm{~m}$ and $5.0 \mathrm{~m}$, at different distances from each other over the entire length of the analysed area. The locations of sample collection were close to the piezocone research points. The results presented are the average test results for each group of samples collected from a certain depth.

The basic physical properties of peat were determined. The organic content was determined using the method of loss on ignition (LOI) in accordance with the Standard PN-EN 15935:2013-02 (Polish Committee for Standardization, 2013). The method is widely used by researchers (Hoogsteen et al., 2015).

Table 1 shows the basic physical properties of the tested peat.

Table 1. Physical properties of the tested peat

\begin{tabular}{ccccc}
\hline Peat designation & Pt 1 & Pt 2 & Pt 3 & Pt 4 \\
\hline $\begin{array}{c}\text { Depth, } \mathrm{m} \\
\text { Physical properties }\end{array}$ & 1.2 & 2.2 & 3.8 & 5.0 \\
Unit weight, $\mathrm{kN} / \mathrm{m}^{3}$ & & & & \\
Unit weight of the solid particles, $\mathrm{kN} / \mathrm{m}^{3}$ & 11.7 & 12.8 & 11.5 & 12.3 \\
Water content, \% & 465 & 418 & 449 & 489 \\
Organic content, \% & 90.7 & 84.4 & 92.4 & 84.2 \\
Degree of humification (von Post scale) & $\mathrm{H} 8$ & $\mathrm{H7}$ & $\mathrm{H6}$ & $\mathrm{H6}$ \\
Void ratio & 8.39 & 5.54 & 7.53 & 5.69 \\
\hline
\end{tabular}

It can be seen from Table 1 that the tested peat had a low unit weight $\left(11.5-12.8 \mathrm{kN} / \mathrm{m}^{3}\right.$ ), high water content (up to $489 \%$ ) and a near to medium degree of decomposition. The organic content was estimated to be $84.2 \%$ to $92.4 \%$. The void ratio of the tested peat ranged from 5.54 to 8.39 .

The tested peat is quasi-fibrous and amorphous. The structure of peat depends on the depth. The highest degree of decomposition is characteristic of organic soil at the lowest depth. It can be related to the changes in the ground water level.

\subsection{Methods}

Piezocone tests were performed for 18 points with numbers from S1 to $\mathrm{S} 18$ to the depth of about $10 \mathrm{~m}$. The test points were located every 15 $\mathrm{m}$ along the section under consideration. Piezocone test locations are shown in Figure. 1. During the CPTU tests, the cone resistance $q_{c}$, sleeve friction $f_{\mathrm{s}}$ and water pressure $u_{2}$ were measured.

The one-dimensional constrained modulus $M$, also known as $E_{\text {oed }}$ (European Committee for Standardization, 2007a), can be determined 
using the following equation (European Committee for Standardization,

$$
M=\alpha q_{\mathrm{c}^{\prime}}
$$

where $\alpha$ is a coefficient depending on the local experience.

Mitchel and Gardner (1975) performed a detailed review of the relationship between the constrained modulus and cone resistance, and Sanglerat (1972) presented $\alpha$ values for different soil types with different cone resistance values. Table 2 shows $\alpha$ values directly for peat.

Table 2. The $\alpha$ values for peat (Sanglerat, 1972)

\begin{tabular}{cc}
\hline Water content of peat $w_{\mathbf{1}} \%$ & $\alpha$ \\
\hline $50<w<100$ & $1.5<\alpha<4.0$ \\
$100<w<200$ & $1.0<\alpha<1.5$ \\
$w>200$ & $0.4<\alpha<1.0$ \\
\hline
\end{tabular}

For the tested peat with water content ranging from $418 \%$ to $489 \%$, it was assumed that the $\alpha$ ranged from 0.4 to 1.0 .

The constrained modulus is typically calculated using correlations with the corrected cone resistance $q_{\mathrm{t}}$ (Mayne, 2006, 2007; Meigh, 1987; Robertson, 2009; Senneset et al.,1989; Schmertmann, 1978). The cone resistance $q_{\mathrm{t}}$ can be determined from the equation (Lunne et al., 1997; Mayne, 2007; Robertson, 1990; Senneset et al., 1989; Tschuschke \& Waliński, 2005):

$$
q_{\mathrm{t}}=q_{\mathrm{c}}+u_{2}(1-a)
$$

where $q_{\mathrm{c}}$ is the measured cone resistance, $u_{2}$ is the pore water pressure, and $a$ is the net area ratio with a value from 0.70 to 0.85 (Robertson \& Cabal, 2014); in the current study, it was assumed that $a=0.75$.

The constrained modulus can also be calculated from the equation given below (Mayne, 2006, 2007; Meigh, 1987; Robertson, 2009; Senneset et al., 1989; Schmertmann, 1978).

$$
M=\alpha_{\mathrm{M}}\left(q_{\mathrm{t}}-\sigma_{\mathrm{v} 0}\right)
$$

where $\alpha_{\mathrm{M}}$ is a coefficient depending on the local experience, and $\sigma_{\mathrm{v} 0}$ is the in-situ total vertical stress.

Values of the $\alpha_{M}$ coefficient presented in the literature apply mainly to clays and sands. Generally, $\alpha_{M}$ varies with values from 1 to 10 (Mayne, 2006, 2007; Meigh, 1987; Senneset et al., 1989). Robertson (2009) 
suggested values of $\alpha_{M}$ coefficients ranging from 2 to 14. For organic clays, $\alpha_{M}$ value from 1 to 2 may be appropriate (Mayne, 2006, 2007). An even lower value of $\alpha_{M}$ coefficient should be expected for peat. In the present study, it was assumed that, for peat, $\alpha_{M}$ value from 0.4 to 1.0 would be appropriate.

Oedometer tests were performed using a set of oedometers with automatic registration of displacement sensor readings presented in Figure. 2.

Tests were carried out on peat samples with an initial height of $20 \mathrm{~mm}$ and a diameter of $63.5 \mathrm{~mm}$. The peat samples were tested in accordance with the European Standard EN ISO 17892-5:2017 (European Committee for Standardization, 2017b) at different vertical stresses $\sigma_{\mathrm{v}}$ '. Table 3 shows the $\sigma_{\mathrm{v}}{ }^{\prime}$ values for the tested peat. In Table 3, the applied stresses are marked with "+", while the omitted stresses with "-".

Table 3. The $\sigma_{v}{ }^{\prime}$ values for the tested peat

\begin{tabular}{ccccc}
\hline \multirow{2}{*}{ Vertical stress $\sigma_{\mathrm{v}}{ }^{\prime}, \mathrm{kPa}$} & \multicolumn{4}{c}{ Peat designation } \\
\cline { 2 - 5 } & Pt 1 & Pt 2 & Pt 3 & Pt 4 \\
\hline 15 & + & + & + & + \\
32 & + & + & + & + \\
64 & + & + & + & + \\
96 & - & - & - & + \\
128 & + & + & - & - \\
\hline
\end{tabular}

Due to the high compressibility of samples and the technical capabilities of oedometers, the maximum vertical stresses for peat Pt 3 and Pt 4 were equal, respectively, $64 \mathrm{kPa}$ and $96 \mathrm{kPa}$.

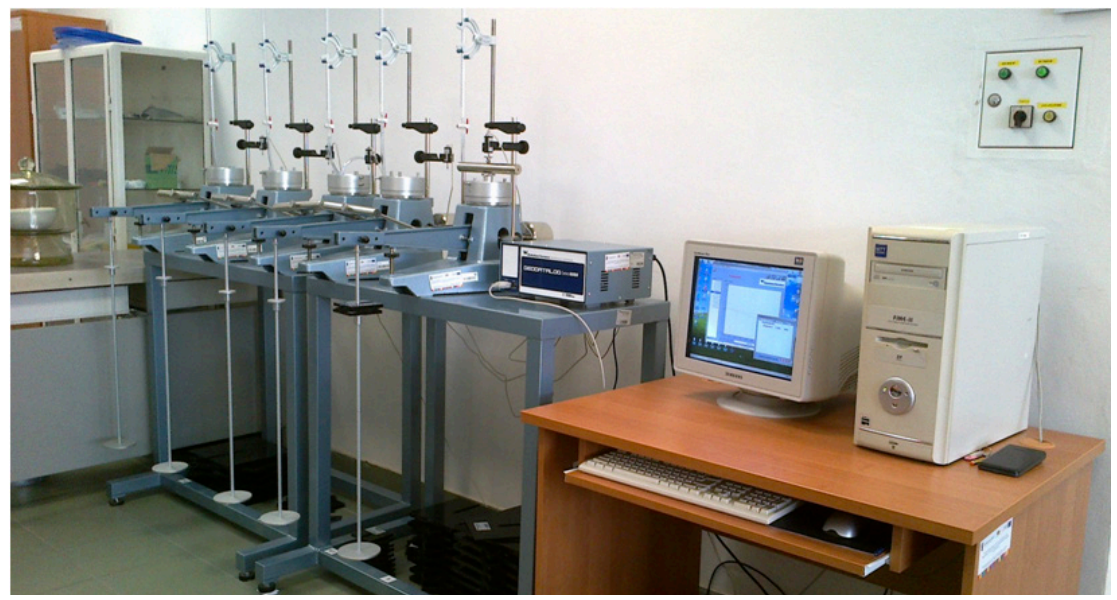

Figure 2. Set of oedometers 
From the oedometer tests, the constrained modulus of soil was determined by measuring the sample height changes under the applied stress. The constrained modulus can therefore be calculated using the formula:

$$
M=\frac{\Delta \sigma_{\mathrm{vi}}{ }^{\prime}}{\Delta \varepsilon}=\frac{\Delta \sigma_{\mathrm{vi}} h_{\mathrm{i}}}{\Delta h_{\mathrm{i}}},
$$

where $\Delta \sigma_{\mathrm{vi}}{ }^{\prime}$ is the effective vertical stress increment, $\Delta \varepsilon$ is a strain, $h_{\mathrm{i}}$ is the initial height of the sample, and $\Delta h_{\mathrm{i}}$ is the change in the height of the sample due to the stress change.

\section{Results and discussion}

\subsection{Piezocone tests}

Similar dependencies of the parameters $q_{c}, f_{\mathrm{s}}$ and $u_{2}$ on the depth were obtained in all 18 research points. The sample CPTU test results in point S5 are shown in Figure 3. Figure 3 also shows the calculated averaged values of cone resistance $q_{\text {cav }}$, sleeve friction $f_{\text {sav }}$ and water pressure $u_{2 \mathrm{av}}$ for each separated soil layer.

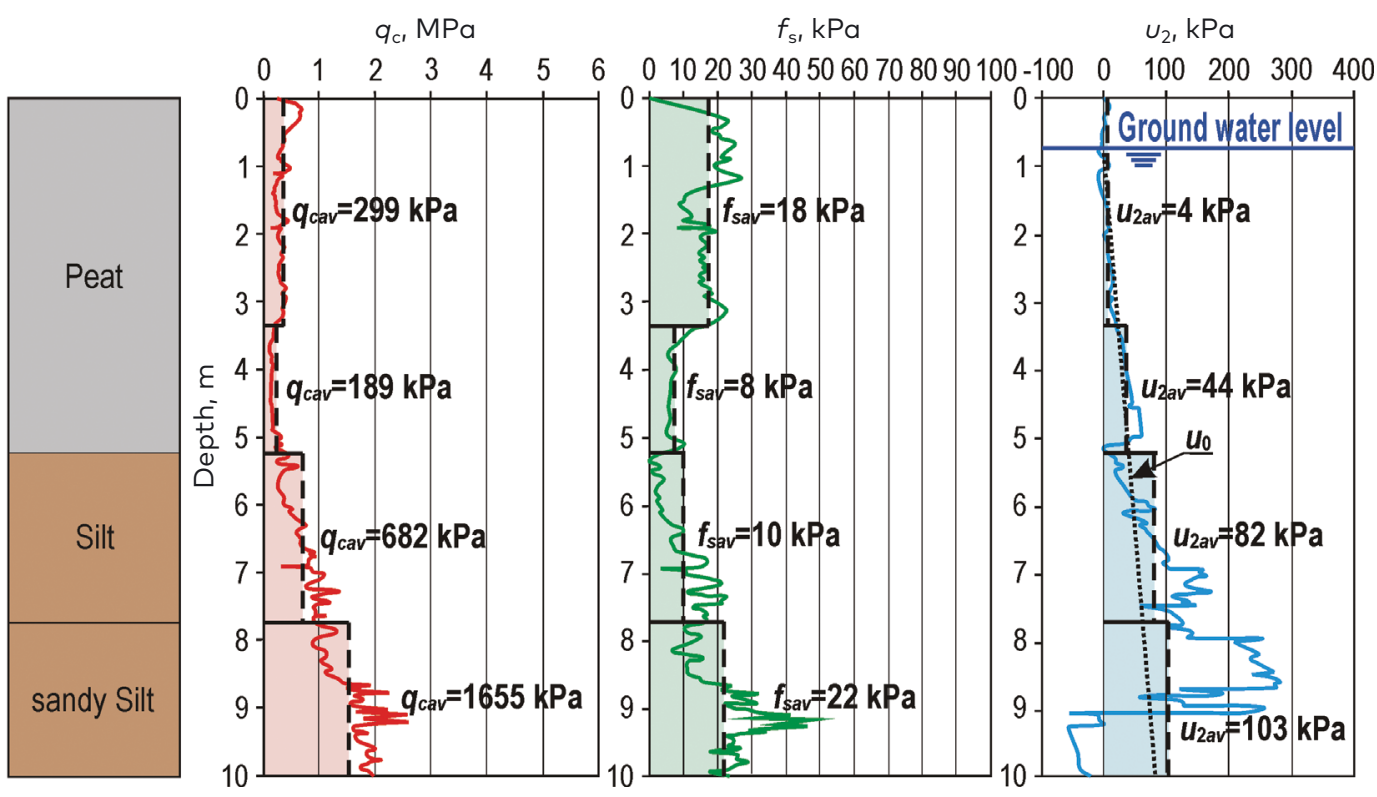

Figure 3. CPTU test results in research point S5 
Table 4. Averaged values of cone resistances $q_{\mathrm{cav}}$ and $q_{\mathrm{tav}}$ in the peat layers

\begin{tabular}{|c|c|c|c|c|c|c|c|}
\hline Research point & $\begin{array}{c}\text { Depth, } \\
\text { m }\end{array}$ & $\begin{array}{l}q_{\text {cavi }} \\
\mathrm{kPa}\end{array}$ & $\begin{array}{l}q_{\text {tav }} \\
\mathrm{kPa}\end{array}$ & Research point & $\begin{array}{c}\text { Depth, } \\
\text { m }\end{array}$ & $\begin{array}{l}q_{\text {cavi }} \\
\mathrm{kPa}\end{array}$ & $\begin{array}{l}q_{\text {tavi }} \\
\mathrm{kPa}\end{array}$ \\
\hline \multirow{2}{*}{ S1 } & $0.0-1.8$ & 397 & 400 & \multirow{2}{*}{59} & $0.0-4.9$ & 199 & 200 \\
\hline & $1.8-3.0$ & 194 & 200 & & $4.9-7.5$ & 94 & 100 \\
\hline \multirow{2}{*}{$\mathrm{S} 2$} & $0.0-2.0$ & 397 & 400 & \multirow{2}{*}{$\mathrm{S} 10$} & $0.0-3.7$ & 299 & 300 \\
\hline & $2.0-3.7$ & 89 & 100 & & $3.7-5.0$ & 193 & 200 \\
\hline \multirow{2}{*}{ S3 } & $0.0-3.2$ & 293 & 300 & \multirow{2}{*}{ S11 } & $0.0-2.0$ & 199 & 200 \\
\hline & $3.2-4.1$ & 185 & 200 & & $2.0-3.0$ & 193 & 200 \\
\hline \multirow{2}{*}{ S4 } & $0.0-4.1$ & 193 & 200 & \multirow{2}{*}{$\mathrm{S} 12$} & $0.0-2.8$ & 199 & 200 \\
\hline & $4.1-5.0$ & 283 & 300 & & $2.8-4.9$ & 93 & 100 \\
\hline \multirow{2}{*}{ S5 } & $0.0-3.3$ & 299 & 300 & \multirow{2}{*}{$\mathrm{S} 13$} & $0.0-3.2$ & 294 & 300 \\
\hline & $3.3-5.2$ & 189 & 200 & & $3.2-5.0$ & 86 & 100 \\
\hline \multirow{3}{*}{ S6 } & $0.0-1.3$ & 599 & 600 & \multirow{2}{*}{ S14 } & $0.0-2.1$ & 299 & 300 \\
\hline & $1.3-4.4$ & 299 & 300 & & $2.1-4.7$ & 287 & 300 \\
\hline & $4.4-6.3$ & 193 & 200 & \multirow{2}{*}{ S15 } & $0.0-3.0$ & 294 & 300 \\
\hline \multirow{3}{*}{ S7 } & $0.0-1.2$ & 599 & 600 & & $3.0-4.3$ & 87 & 100 \\
\hline & $1.2-3.3$ & 299 & 300 & \multirow{2}{*}{ S16 } & $0.0-3.0$ & 197 & 200 \\
\hline & $3.3-4.7$ & 187 & 200 & & $3.0-4.2$ & 89 & 100 \\
\hline \multirow{3}{*}{ S8 } & $0.0-1.5$ & 499 & 500 & \multirow{2}{*}{ S17 } & $0.0-2.5$ & 199 & 200 \\
\hline & $1.5-4.2$ & 199 & 200 & & $2.5-4.7$ & 99 & 100 \\
\hline & $4.2-5.9$ & 87 & 100 & $\mathrm{~S} 18$ & $0.0-2.1$ & 396 & 400 \\
\hline
\end{tabular}

Table 5. Cone resistances and the total stresses at considered depths

\begin{tabular}{cccc}
\hline Depth, $\mathbf{~ m}$ & $\mathbf{q}_{\text {cav } \mathbf{~}} \mathbf{k P a}$ & $\mathbf{q}_{\text {tavı }} \mathbf{k P a}$ & $\sigma_{\mathbf{v} \mathbf{0}, \mathbf{k P a}}$ \\
\hline 1.2 & 325 & 328 & 14.0 \\
2.2 & 237 & 241 & 26.3 \\
3.8 & 170 & 179 & 45.7 \\
5.0 & 161 & 171 & 60.0 \\
\hline
\end{tabular}

Only peat layers will be considered further in the study. Thus, Table 4 shows the averaged values of the cone resistances $q_{\text {cav }}$ and $q_{\mathrm{tav}}$ in research points from S1 to S18 for peat layers only. The cone resistances $q_{\text {tav }}$ were calculated using Formula (2) for the values of cone resistance $q_{\text {cav }}$ and water pressure $u_{\text {2av }}$ averaged within a separate layer.

The averaged values of cone resistances at the considered depths, $1.2 \mathrm{~m}, 2.2 \mathrm{~m}, 3.8 \mathrm{~m}$ and $5.0 \mathrm{~m}$, are presented in Table 5. Additionally, Table 5 shows the total vertical stress values $\sigma_{\mathrm{v} 0}$ at each depth. 
In Table 5, the cone resistances for the tested peat decreased with From In-Situ depth. The corrected cone resistances $q_{\mathrm{t}}$ in peat layers presented in the literature are similar to those obtained in the current study and generally range from about $100 \mathrm{kPa}$ to $500 \mathrm{kPa}$ (Carlsten, 2000; Den Chann, 1997; Edil, 2001; Long, 2005; Long \& Boylan, 2012; Mitachi, 1998).

\subsection{Oedometer tests}

Figure 4 shows the consolidation curves as a result of the oedometer tests.

The vertical strain of peat Pt 4 from the depth $5.0 \mathrm{~m}$ was the highest of all tested peats. This corresponds to the CPTU tests results because the higher soil compressibility corresponds to a lower value of the cone resistance.

The constrained modulus of peat calculated from Formula (4) in relation to the effective stress $\sigma_{\mathrm{v}}{ }^{\prime}$ is shown in Figure 5.

The constrained modulus directly depends on the effective stress. The effective stresses of $15 \mathrm{kPa}$ and lower are closest to the in-situ conditions. It can be seen in Figure 5 that for this range of effective stress, peat Pt 4 had the lowest constrained modulus, while peat Pt 2 had the highest.

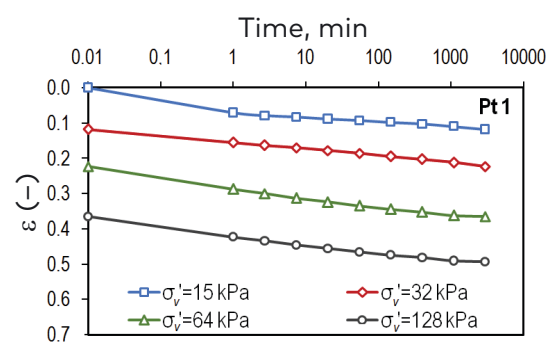

a)

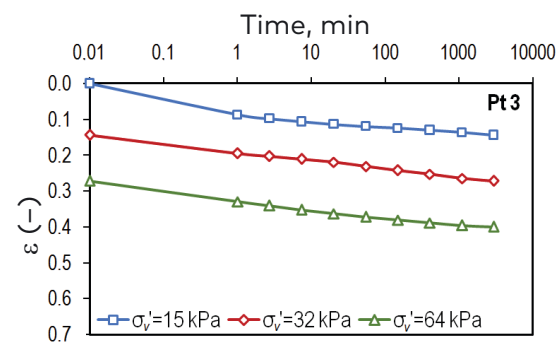

c)

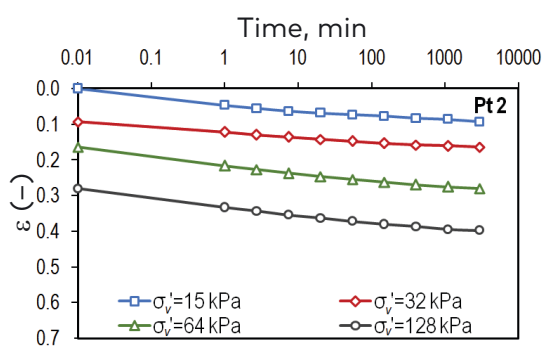

b)

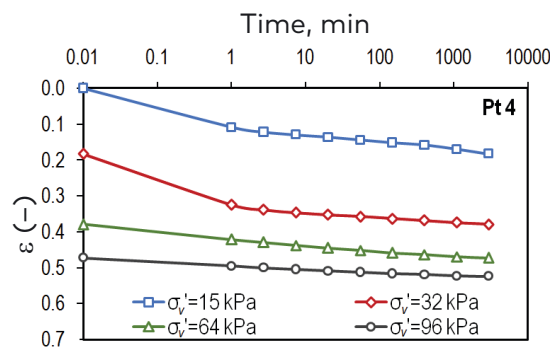

d)

Figure 4. Strain versus time curves for the tested peat: a) Pt $1 ;$ b) Pt 2 ; c) Pt $3 ;$ d) Pt 4 


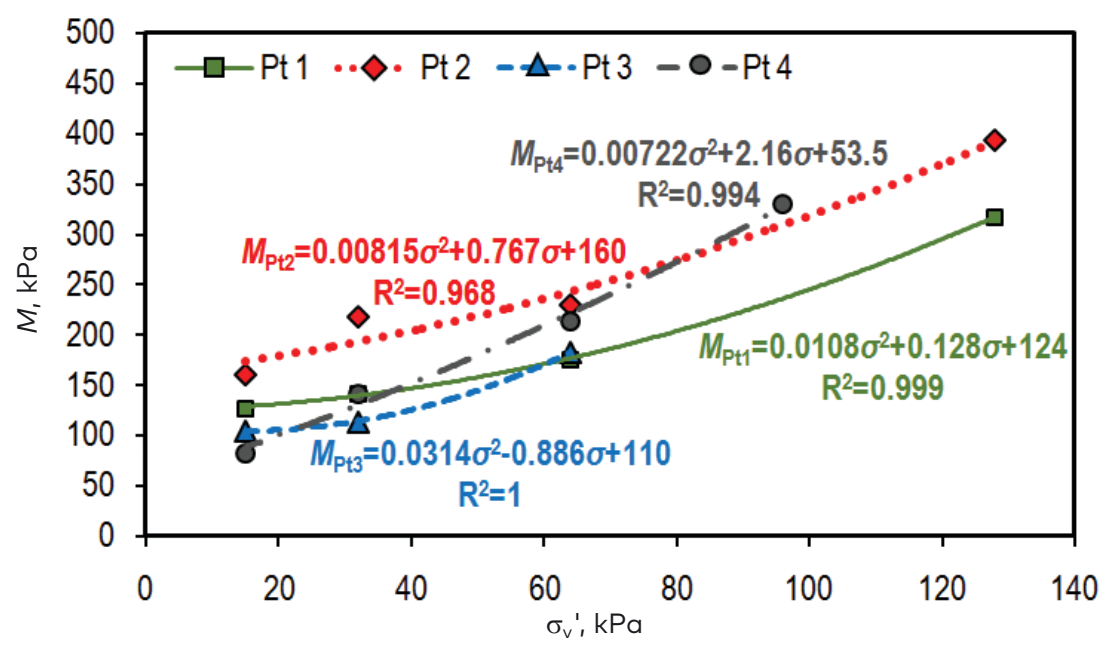

Figure 5. The constrained modulus of peat in relation to effective stress

The constrained modulus of peat obtained from the oedometer tests ranged, depending on the effective stress, from approximately $100 \mathrm{kPa}$ to $400 \mathrm{kPa}$ and was very close to the values presented in the literature (Gabryś \& Szymański, 2010; Wierzbicki et al., 2015).

\subsection{Comparison of research methods}

To compare the constrained modulus obtained from the oedometer and piezocone penetration tests, effective stress at in-situ conditions the $\sigma_{\text {vin }}$ ' was determined. The calculations considered the average ground water level, which was equal to $0.7 \mathrm{~m}$, and the buoyant unit weight of peat. Due to the very high values of the coefficient of determination $R^{2}$ describing the correlation between the constrained modulus and effective stress, the modulus at $\sigma_{\text {vin }}$ ' stress was determined using functions from Figure 5. Table 6 shows the results of calculations.

Table 6. The effective stress and constrained modulus at in-situ conditions

\begin{tabular}{cccc}
\hline Peat designation & Depth, $\mathbf{m}$ & $\sigma_{\text {vin }}{ }^{\prime}, \mathbf{k P a}$ & $\mathbf{M}, \mathbf{k P a}$ \\
\hline Pt 1 & 1.2 & 8.87 & 126 \\
Pt 2 & 2.2 & 9.44 & 168 \\
Pt 3 & 3.8 & 10.5 & 104 \\
Pt 4 & 5.0 & 11.3 & 79 \\
\hline
\end{tabular}


The constrained modulus from piezocone penetration tests was From In-Situ calculated using the values shown in Table 5 for $\alpha$ and $\alpha_{M}$ coefficients for Road Application ranging from 0.4 to 1.0 .

Figure 6 presents the final values of the constrained modulus depending on the research method and depth.

In Figure 6, the constrained modulus determined from the piezocone penetration tests decreased with depth. The constrained modulus is strictly related to the cone resistances $q_{\mathrm{c}}$ and $q_{\mathrm{t}}$ that also decrease with depth. The constrained modulus from the oedometer tests with the highest value was at a depth of $2.2 \mathrm{~m}$, and the lowest was at a depth of $5.0 \mathrm{~m}$.

In general, as shown in Figure 6 , the values of the $\alpha$ coefficient presented in the literature for peat are correct. However, the constrained modulus results from the oedometer tests are compared better with the upper limit of $0.7 q_{c}$. The optimal range of the $\alpha_{M}$ coefficient is from 0.4 to 0.8 . The constrained modulus results from the oedometer and piezocone tests had comparable values.

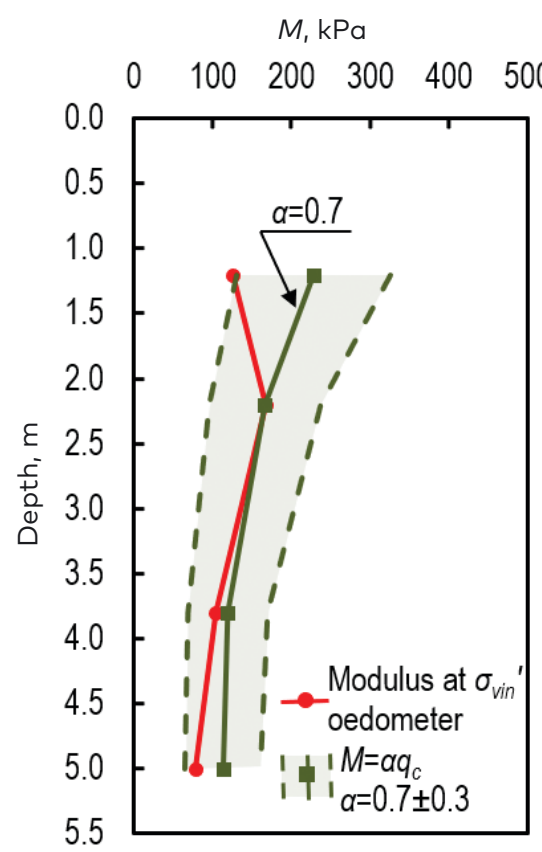

a) measured cone resistance $q_{c}$

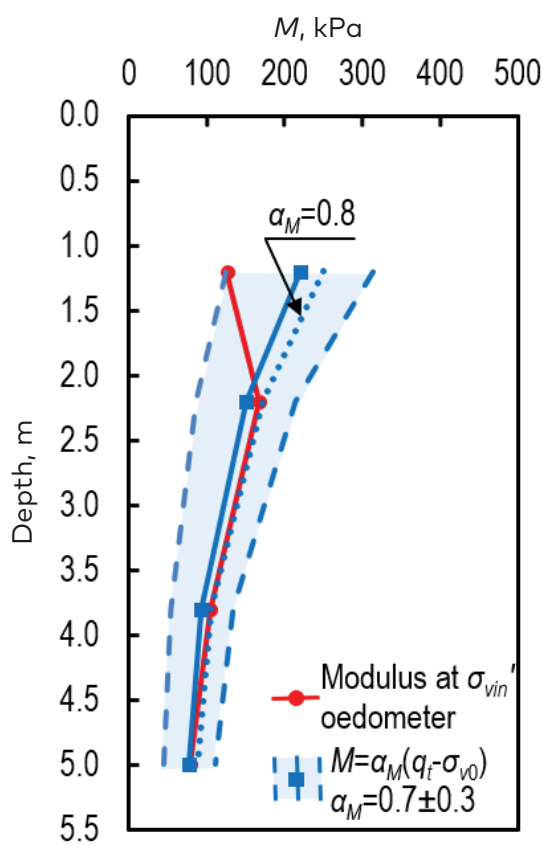

b) corrected cone resistance $q_{t}$

Figure 6. The constrained modulus of peat from the oedometer and CPTU tests determined on the basis of the measured cone resistance $q_{c}$ and corrected cone resistance $q_{t}$ 


\section{Conclusions}

The following general conclusions may be formulated from the performed analysis.

1. The constrained modulus of peat was determined on the basis of the measured cone resistance $q_{c}$ and corrected cone resistance $q_{\mathrm{t}}$. The value of the constrained modulus depended on the $\alpha$ and $\alpha_{M}$ coefficients which should be obtained on the basis of local experience.

2. In the current study, the $\alpha$ and $\alpha_{M}$ coefficients adopted from the literature gave satisfactory results.

3. For the tested peat, the optimal range of the $\alpha$ coefficient was from 0.4 to 0.7 . The $\alpha_{M}$ coefficient ranged from 0.4 to 0.8 .

4. The constrained modulus of peat obtained from the oedometer tests, depending on the effective stress, ranged from approximately $100 \mathrm{kPa}$ to $400 \mathrm{kPa}$ and was close to the values presented in the literature.

5. The constrained modulus of the tested peat decreased with depth, which both research methods proved.

6. Piezocone penetration tests are an effective method of obtaining accurate values of the constrained modulus. However, comparing the results with another research method is recommended, particularly for peat.

7. In the author's opinion, the laboratory tests give more reliable results, provided that the samples have been properly collected, transported and stored. However, the analysis performed showed that the constrained modulus could also be predicted from the results of field tests.

\section{Funding}

The research has been carried out at Bialystok University of Technology and supported by Polish financial resources on science under project no. W/WB-IIL/7/2019.

\section{REFERENCES}

Atkinson, J. (2007). The Mechanics of Soils and Foundations (2nd ed.). Routledge Taylor \& Francis Group.

Bo, M. W., Choa, V., \& Wong, K. S. (2005). Reclamation and Soil Improvement on Ultra-Soft Soil. Ground Improvement, 9(1), 23-31. 
https://doi.org/10.1680/grim.9.1.23.58542

Carlsten, P. (2000). Geotechnical Properties of Some Swedish Peats. In Proceedings of the 13th Nordic Geotechnical Meeting, Helsinki, Finland, 5-6 January 2000.

Den Chann, E. J. (1997). An Overview of the Mechanical Behavior of Peats and Organic Soils and Some Appropriate Construction Techniques. In Proceedings of the Conference on Recent Advances in Soft Soil Engineering, Kuching, Sarawak, Malaysia, 5-7 March 1997.

Duraisamy, Y., Huat, B. B. K., \& Aziz A. A. (2007). Methods of Utilizing Tropical Peat Land for Housing Scheme. American Journal of Environmental Sciences, 3(4), 259-264. https://doi.org/10.3844/ajessp.2007.259.264

Edil, T. B. (2001). Site Characterization in Peat and Organic Soils. In Proceedings of the International Conference on In-Situ Measurement of Soil Properties and Case Histories, Bali, Indonesia, 21-24 May 2001.

Edil, T. B. (2003). Recent Advances in Geotechnical Characterization and Construction Over Peat and Organic Soils. In Proceedings of the 2nd International Conference on Advances in Soft Soil Engineering and Technology, Putrajaya, Malaysia, 2-4 July 2003.

European Committee for Standardization. (2007a). EN 1997-2:2007: Eurocode 7 Geotechnical Design - Part 2: Ground Investigation and Testing.

European Committee for Standardization. (2017b). EN ISO 17892-5:2017: Geotechnical Investigation and Testing - Laboratory Testing of Soil - Part 5: Incremental Loading Oedometer Test.

Gabryś, K., \& Szymański, A. (2010). The Analysis of Consolidation in Organic Soils. Annals of Warsaw University of Life Sciences, 42(2), 261-270. https://doi.org/10.2478/v10060-008-0084-4

Hartlen, J., Carlsten, P., \& Wolski, W. (1996). Design and Construction Methods. In J. Hartlen, W. Wolski (Eds.), Embankments on Organic Soils (pp. 240-407). Elsevier. https://doi.org/10.1016/S0165-1250(96)80009-5

Head, K. H. (1994). Manual of Soil Laboratory Testing. Volume 2 (2nd ed.). John Wiley \& Sons, Inc.

Hoogsteen, M. J. J., Lantinga, E. A., Bakker, E. J., Groot, J. C. J., \& Tittonell, P. A. (2015). Estimating Soil Organic Carbon through Loss on Ignition: Effects of Ignition Conditions and Structural Water Loss. European Journal of Soil Science, 66(2), 320-328. https://doi.org/10.1111/ejss.12224

Huat, B. B. K., Asadi, A., \& Kazemian, S. (2009). Experimental Investigation on Geomechanical Properties of Tropical Organic Soils and Peat. American Journal of Engineering and Applied Sciences, 2(1), 184-188. https://doi.org/10.3844/ajeassp.2009.184.188

Huat, B. B. K., Maail, S., \& Mohammad, T. A. (2005). Effect of Chemical Admixtures on the Engineering Properties of Tropical Peat Soils. American Journal of Applied Sciences, 2(7), 1113-1120. https://doi.org/10.3844/ajassp.2005.1113.1120

Huat, B. B. K., Prasad, A., Asadi, A., \& Kazemian, S. (2014). Geotechnics of Organic Soils and Peat. Taylor \& Francis Ltd. https://doi.org/10.1201/b15627 
Khalid, N., Arshad, M. F., Mukri, M., Mohamad, K., \& Kamarudin, F. (2015). Influence of Nano-Soil Particles in Soft Soil Stabilization. Electronic Journal of Geotechnical Engineering, 20(2), 731-738.

Kumar, R., \& Jain, P. K. (2013). Expansive Soft Soil Improvement by Geogrid Encased Granular Pile. International Journal on Emerging Technologies, 4(1), 55-61.

Lechowicz, Z., \& Szymański, A. (2002). Deformation and Stability of Embankments on Organic Soils. Warsaw University of Life Sciences Press. (In Polish).

Long, M. (2005). Review of Peat Strength, Peat Characterisation and Constitutive Modelling of Peat with Reference to Landsides. Studia Geotechnica et Mechanica, 27(3-4), 67-90.

Long, M., \& Boylan, N. (2012). In-Situ Testing of Peat - a Review and Update on Recent Developments. Geotechnical Engineering Journal of the SEAGS \& AGSSEA, 43(4), 41-45.

Long, M., \& Boylan, N. (2013). Prediction of Settlements in Peat Soils. Quarterly Journal of Engineering Geology and Hydrogeology, 46(3), 303-322. https://doi.org/10.1144/qjegh2011-063

Lunne, T., Robertson, P. K., \& Powell, J. J. M. (1997). Cone Penetration Testing in Geotechnical Practice. Blackie Academic, EF \& FN Spon.

Majeed, Z. H., \& Taha, M. R. (2012). Effect of Nanomaterial Treatment on Geotechnical Properties of a Penang Soft Soil. Journal of Asian Scientific Research, 2(11), 587-592.

Mangan, J. P. (1994). Construction on Peat: State of Art in France. In Proceedings of International Workshop on Advances in Understanding and Modelling the Mechanical Behaviour of Peat, Delft, Netherlands, 16-18 June 1993.

Mayne, P. W. (2006). In-Situ Test Calibrations for Evaluating Soil Parameters. In Proceedings of the Singapore Workshop, Singapore, 29 November to 1 December 2006. https://doi.org/10.1201/NOE0415426916.ch2

Mayne, P. W. (2007). Cone Penetration Testing: A Synthesis of Highway Practice. Transportation Research Board.

Meigh, A. C. (1987). Cone Penetration Testing: Methods and Interpretation. Construction Industry Research and Information Association. https://doi.org/10.1016/B978-0-408-02446-4.50004-2

Mitachi, T. (1998). Method for Predicting In Situ Undrained Strength of Highly Organic Soil Based on the Value of Suctin and Unconfined Compressive Strength. In Proceedings of the International Symposium on Problematic Soils, Sendai, Japan, 28-30 October 1998.

Mitchell, J. K., \& Gardner, W. S. (1975). In Situ Measurement of Volume Change Characteristics. In Proceedings of the ASCE Specialty Conference on In Situ Measurements of Soil Properties, Raleigh, North Carolina, United States, 1-4 June 1975.

Młynarek, Z., Tschuschke, W., \& Wierzbicki, J. (2006). The Assessment of Variability of CPTU and DMT Parameters in Organic Soils. In Proceedings from the Second International Flat Dilatometer Conference, Washington, D.C., United States, 2-5 April 2006. 
Moon, J.-S., Jung, H. S., Lee, S., \& Kang, S.-T. (2019). Ground Improvement Using Dynamic Compaction in Sabkha Deposit. Applied Sciences, 9(12), 1-16. https://doi.org/10.3390/app9122506

Polish Committee for Standardization. (2013). PN-EN 15935:2013-2: Sludge, Treated Biowaste, Soil and Waste - Determination of Loss on Ignition.

Powrie, W. (2014). Soil Mechanics. Concepts and Applications (3rd ed.). CRC Press Taylor \& Francis Group.

Rahman, Z. A., Sulaiman, N., Rahim, S. A., Idris, W. M. R., \& Lihan, T. (2016). Effect of Cement Additive and Curing Period on Some Engineering Properties of Treated Peat Soil. Sains Malaysiana, 45(11), 1679-1687.

Robertson, P. K. (1990). Soil Classification Using Cone Penetration Test. Canadian Geotechnical Journal, 27(1), 151-158. https://doi.org/10.1139/t90-014

Robertson, P. K. (2009). Interpretation of Cone Penetration Tests - a Unified Approach. Canadian Geotechnical Journal, 46(11), 1337-1355. https://doi.org/10.1139/T09-065

Robertson, P. K., \& Cabal, K. L. (2014). Guide to Cone Penetration Testing for Geotechnical Engineering (6th ed.). Gregg Drilling \& Testing, Inc.

Sanglerat, G. (1972). The Penetrometer and Soil Exploration. Volume 1 (2nd ed.). Elsevier Scientific Publishing Company. https://doi.org/10.1097/00010694-197308000-00009

Schmertmann, J. H. (1978). Guidelines for Cone Penetration Test: Performance and Design. Federal Highway Administration.

Senneset, K., Sandven, R., \& Janbu, N. (1989). Evaluation of Soil Parameters from Piezocone Tests. In In Situ Testing of Soil Properties for Transportation. Transportation Research record 1235 (pp. 24-37). Transportation Research Board.

Tschuschke, W., \& Waliński, M. (2005). CPTU in Soft Post-Flotation Sediments. Studia Geotechnica et Mechanica, 27(3-4), 121-132.

Virsis, E., Paeglitis, A., \& Zarins, A. (2020). Road Design on Low Bearing Capacity Soils. The Baltic Journal of Road and Bridge Engineering, 15(3), 19-33. https://doi.org/10.7250/bjrbe.2020-15.481

Wierzbicki, J., Stefaniak, K., \& Boczkowski, B. (2015). Analysis of Selected Geotechnical Properties of Peat Depending on Its Type and Water Content. Marine Engineering and Geotechnics, 36(3), 212-216. (In Polish)

Wong, L. S., Hashim, R., \& Ali, F. H. (2008). Strength and Permeability of Stabilized Peat Soil. Journal of Applied Sciences, 8(21), 3986-3990. https://doi.org/10.3923/jas.2008.3986.3990

Zainorabidin, A., \& Wijeyesekera, D. C. (2008). Geotechnical Characteristics of Peat. In Proceedings of the Advances in Computing and Technology Conference, The School of Computing and Technology 3nd Annual Conference, London, United Kingdom, 27 January 2008. 


\section{Notations}

$\alpha, \alpha_{M}-$ coefficients dependent on the local experience;

$\varepsilon$ - vertical strain;

$\sigma_{\mathrm{v}}{ }^{\prime}$ - effective vertical stress, $\mathrm{kPa}$;

$\sigma_{\mathrm{v} 0}-$ in-situ total vertical stress, $\mathrm{kPa}$;

$a-$ net area ratio;

$c_{\mathrm{u}}$ - undrained shear strength, $\mathrm{kPa}$;

$f_{\mathrm{s}}$ - sleeve friction, $\mathrm{kPa}$;

$h_{\mathrm{i}}$ - height of the sample, $\mathrm{mm}$;

$M, E_{\text {oed }}$ - constrained modulus, $\mathrm{kPa}$;

$u_{2}$ - pore water pressure, $\mathrm{kPa}$;

$q_{\mathrm{c}}$ - measured cone resistance, $\mathrm{kPa}, \mathrm{MPa}$;

$q_{\mathrm{t}}$ - corrected cone resistance, $\mathrm{kPa}, \mathrm{MPa}$;

$w$ - water content, \%;

CPTU - piezocone penetration test;

DMT - dilatometer test. 